\title{
A Sustainable Control Natural Breeding Technology of Mud Eel, Monopterus Cuchia (Hamilton, 1822) in Bangladesh
}

\author{
Chakraborty BK${ }^{1 *}$, Shahroz $\mathrm{MH}^{2}$ and Salma $\mathrm{AS}^{2}$ \\ ${ }^{1}$ Department of Fisheries, Bangladesh, \\ ${ }^{2}$ Faculty of Fisheries, Bangladesh Agricultural University, Bangladesh \\ *Corresponding author: Binay Kumar Chakraborty, Department of Fisheries, Dhaka, \\ Bangladesh, Tel: 008801715 470855; Email: bborty@gmail.com
}

\section{Research Article \\ Volume 3 Issue 2}

Received Date: April 04, 2019

Published Date: May 10, 2019

DOI: $10.23880 /$ ijoac- 16000165

\section{Abstract}

Very useful control natural breeding indicators Gonado-somatic Index (GSI), fecundity, and length, body weight and gonad weight relationship with fecundity was studied to identify accurate spawning period of Monopterus cuchia over a period of January to December 2017. Highest GSI value was found in the month of May and lowest was recorded in December for both sexes. Length, body weight and gonad weight relationship with fecundity was exponential equation $\left(\ln F=1.3576 \mathrm{e}^{0.1087 x}, \mathrm{R}^{2}=0.8004 ; \ln \mathrm{F}=117.2 \mathrm{e}^{0.0049 \mathrm{x}}, \mathrm{R}^{2}=0.6089\right.$ and $\left.\ln \mathrm{F}=362.35 \mathrm{e}^{0.0229 \mathrm{x}}, \mathrm{R}^{2}=0.696\right)$. Length, body weight and gonad weight data were correlated with fecundity. The highest condition index was found at the value of 2.119542 for female in May 2017 and lowest was recorded at 1.857057 in January 2017. Control natural breeding of M. cuchia was carried out at the two cisterns of Fish Seed Multiplication Farm Sadar, Netrokona as a treatment $\mathrm{T}_{1}$; Nimgachi, Sirajgonj as a treatment $\mathrm{T}_{2}$ and Parbotipur, Dinajpur as a treatment $\mathrm{T}_{3}$. Plastic bowel for first 25 days and cement cistern for second 25 days was developed for nursing of larvae for every treatment. A continuous monitoring was observed to collect fertilized eggs from the mouth of the hole of the berm. Fertilized eggs were collected and stocked in different plastic bowel through a series of collection. The responsive number of female in ovulation was $91.50,78.50$ and $71.00 \%$ and the number of collecting eggs from the hole was at 9218.50, 11010.50 and 13642.00 in treatment $\mathrm{T}_{1}, \mathrm{~T}_{2}$ and $\mathrm{T}_{3}$. The fertility rate was recorded at the rate of $94.50,89.00$ and $85.50 \%$, and the hatching rate was $89.00,84.00$ and $80.50 \%$ in treatment T1, T2 and T3. After 50 days, the final mean weight of fry recorded at 12.55, 12.30 and $12.08 \mathrm{~g}$ in treatment $\mathrm{T}_{1}$, $\mathrm{T}_{2}$ and $\mathrm{T}_{3}$, respectively. So, stocking density of male and female 50:50 in treatment T1 was a sustainable technology of control natural breeding.

Keywords: Monopterus Cuchia; Control Natural Breeding; Fertility Rate; Hatchling Rate; Gonado-Somatic Index; Fecundity; Condition Factor 


\section{International Journal of Oceanography \& Aquaculture}

Abbreviations: GSI: Gonado Somatic Index; FSMF: Fish Seed Multiplication Farm; FCR: Food Conversion Rate; D0: Dissolved Oxygen.

\section{Introduction}

Monopterus cuchia is an important freshwater air breathing, swamp mud eel in Bangladesh. It commonly occurs in the freshwater of Bangladesh, Pakistan, India, Burma and Nepal [1]. Once, indigenous M. cuchia was abundant throughout the country, plenty in mud holes in shallow "beels" and 'boro' paddy field particularly in old Sylhet, Mymensingh and Tangail Districts [2]. But presently this fish is hardly found in the open water system. The biodiversity, natural ecosystem of water bodies are being decreased due to global warming and climate change. $M$. cuchia is enlisted as threatened species $[3,4]$ in Bangladesh because of destruction of the natural habitats, horizontal expansion of agriculture, use of chemicals, fertilizer and pesticide and over exploitation and various ecological changes in its natural habitat. This fish is exported regularly too many countries of south East Asia and Europe. The tribal people belonging to the Garo, Hajong, Shawtali and Koch-Rajbongshi community believes this fish to be therapeutic one and traditionally use for treatment of various ailments, Viz. weakness, anemia, asthma, hemorrhoids and diabetes. Direct consumption of fresh blood of the fish is reported to cure weakness, anemia and asthma [5,6]. Curry prepared by cooking the flesh along with certain herbs or soup prepared from cooking the flesh alone are known to cure anemia, piles and diabetes $[7,8]$. The average protein content per $100 \mathrm{gm}$ of raw flesh is $18.7 \mathrm{gm}$, while the concentrations of other nutrients are $0.8 \mathrm{gm}$ fats, $2.4 \mathrm{gm}$ carbohydrate and $185 \mathrm{gm}$ calcium (www.mcgill.ca). Presence of amino acids viz. Alanine, Arginine, Glycine, Histidine, Leucine and Methionine has also been reported from this species [9]. For such nutritional importance, there is a tremendous demand of cuchia in the international market. Annual total catch of M. cuchia capture and aquaculture was recorded to be 8082.37 , $7824.11,7422.99,7223.54$ and $6954.74 \mathrm{mt}$ in the year 2013, 2014, 2015, 2016 and 2017, respectively and a decreasing trend of total population of mud eel in the country was identified between 2013 and 2017 [10].

Reproductive potential of a population is one of the basic exigencies to designate the individuals of that population in respect to their gonad conditions [11]. It is very important to assess the yearly breeding cycle of $M$. cuchia to make success in breeding practice. Knowledge of gonad development and the spawning season of a species allow subsequent studies on spawning frequency of its population, which is very important for its management [12]. Gonado Somatic Index (GSI) value of cuchia is helpful to identify accurate spawning cycle of M. cuchia. A sustainable control natural breeding of mud eel can play a positive role to develop a sustainable aquaculture of cuchia production. Considering the importance of this species in nutritional, medicinary, economic and biodiversity point of view, this control natural breeding technology of $M$. cuchia should be developed by controlling natural habitat.

\section{Materials and Methods}

On the basis of biological and geographical point of view Fish Seed Multiplication Farm (FSMF) Sadar, Netrokona (Latitude: $24^{\circ} 53^{\prime} 0.67^{\prime \prime} \mathrm{N}$; Longitude: $90^{\circ} 43^{\prime}$ 44.33" E); Nimgachi, Sirajgonj (Latitude $24^{\circ} 27^{\prime} 4.788^{\prime \prime} \mathrm{N}$; Longitude: $89^{\circ} 42^{\prime} 2.304^{\prime \prime}$ E) and Parbotipur, Dinajpur (Latitude: $25^{\circ} 39^{\prime} 49.28 " \mathrm{~N}$; Longitude: 88 55' 51.35" E) was selected for control natural breeding of M. cuchia. Control natural breeding of $M$. cuchia was carried out at the six cisterns of Fish Seed Multiplication Farm Sadar, Netrokona as a treatment $\mathrm{T}_{1}$; Nimgachi, Sirajgonj as a treatment $\mathrm{T}_{2}$ and Parbotipur, Dinajpur as a treatment $\mathrm{T}_{3}$ with each area of $28 \mathrm{~m} 3(8.0 \mathrm{~m} \times 3.0 \mathrm{~m} \times 1.0 \mathrm{~m})$, respectively during 2016-2017. M. cuchia was stocked at a density of male and female 50:50, 70:70 and 100:100 in treatment $\mathrm{T}_{1} \mathrm{~T}_{2}$ and $\mathrm{T}_{3}$ with an average weight of male $302 \pm 14.30 \mathrm{~g}$ and female $300 \pm 11.77 \mathrm{~g}$ to identify a suitable stocking density. Brood of M. cuchia was collected from the wetland of Netrokona, Sirajgonj and Dinajpur district during November to December 2016. Brood fish was reared in the cistern of three different Fish Seed Multiplication Farms from January to May 2017. Live feeds carp fry, small fish and earthworm were provided twice daily at the rate of $3 \%$ body weight as a daily ration.

The bottom of the cistern was developed by four layers for control natural breeding of mud eel. First layer $(15 \mathrm{~cm})$ was filled with clay, second layer $(15 \mathrm{~cm})$ was covered with compost (cowdung, straw and water hyacinth as per requirement, lime $6.0 \mathrm{~kg}$, urea $3 \mathrm{~kg}$ and TSP $6.0 \mathrm{~kg}$ ); third layer $(1 \mathrm{~cm})$ was filled with 4-5 days dry banana leaf and fourth layer $(15 \mathrm{~cm})$ was filled as same as first layer with clay. The berm was developed by clay with a volume of $60 \mathrm{~cm}$ inside of the cistern. Berm was covered with bamboo made chatai for a shelter and protected the eggs from higher temperature. M. cuchia made holes in the berm and built nests inside the holes. The cisterns were filled with water with a depth of $0.41 \mathrm{~m}$ and the level was maintained throughout by periodic felling and water hyacinth (aquatic vegetation) was installed in every cistern. 


\section{International Journal of Oceanography \& Aquaculture}

About 62 samples of M. cuchia were collected for fecundity study. The ovary of each fish was dissected very carefully and preserved in 10\% buffered formalin for further study. The weight of the ovary was measured with the help of a sensitive portable electronic balance (Model HL 400 EX). The mean gonado somatic index (GSI) of $M$. cuchia was calculated according to the formula: GSI = (Gonad Weight / Total weight) $\times 100$. Von Vayer method was applied to estimate the fecundity of relatively large size eggs of M. cuchia [12].

The mean gonado somatic index (GSI) and external characteristics were used to identify a male and female. Sex ratios were calculated as the number of female per male, based on sex determination criteria. Sexual maturity of broods was confirmed by observing the external appearance and shape of the genital organ. In this experiment no hormone or induced breeding technique was designed due to lower fecundity of M. cuchia. According to GSI value a continuous monitoring was observed to find out fertilized eggs in the month of April to June. After ovulation fertilized eggs came out in front of the hole. A safety shelter for cuchia larvae and fry was developed by installing plastic made broom in every plastic vowel and an aeration system was continued in every vowel. When fertilized eggs were found in mouth of hole, these fertilized eggs were collected by a scope net and stocked in a plastic bowel with 10 liter water volume of nine plastic bowls through a series of collection until complete of natural breeding. Larvae were cultured for 25 days in plastic bowel. At the age of 25 days fry was transferred into cement cisterns with a volume of $24 \mathrm{~m}^{3}$ $(8 \mathrm{~m} \times 3 \mathrm{~m} \times 1 \mathrm{~m})$ each and every treatment was designed with two cisterns. The culture period was continued for another 25 days from May to July, 2017. The stocking density was at the rate of number $70 \mathrm{~m}^{-1}$ with an initial length and weight of $1.81 \pm 0.2 \mathrm{~cm}$ and $0.011 \pm 0.1 \mathrm{~g}$.

Yolk sac of the larvae was dissolved within 10 to 12 days. At that time one boiled egg's yolk of hen or duck was supplied for one 0.10 million spawn for its ration. After two days only live feed Moyna (zooplankton) was provided at $400 \%$ daily ration for $1^{\text {st }}$ to $5^{\text {th }}$ days and $200 \%$ daily ration maintained for $6^{\text {th }}$ to 10 days of total biomass. In order to meet up the increasing dietary demand small pieces of earthworm and carp spawn was supplied at 5 to $10 \%$ of the total biomass per day. Daily ration was adjusted by estimating the standing crop once in each five days by random sampling of the stock. Growth in terms of length $(\mathrm{cm})$ and weight $(\mathrm{g})$ were assessed through periodic sampling at 5 days intervals. Mean increment in length and weight, health status assessment were calculated from random samples of 50 individuals from each cistern. Growth in terms of length and weight, survival (\%), food conversion rate (FCR) was estimated [13]. Physico-chemical water quality parameters measured weekly. A centigrade thermometer measured the temperature of water. HACH water test kit (Model-FF2, USA) was used to measure $\mathrm{pH}$, dissolved oxygen (DO) and alkalinity. Water quality of Cistern was measured regularly following standard methods [14].

\section{Results}

Identification of male and female maturity stages of $\mathrm{M}$. Cuchia by observing the external appearance and shape of the genital organ (Table 1). Gonad of male and female was identified by internal dissecting (Figures $1 \mathrm{a} \& 1 \mathrm{~b}$ ).

\begin{tabular}{|c|c|c|c|}
\hline \multirow{2}{*}{ Sl.No } & \multirow{2}{*}{ Indication } & \multicolumn{2}{|c|}{ Key Characteristics } \\
\cline { 3 - 4 } & Body Size & Male & Female \\
\hline 1 & Color & $\begin{array}{c}\text { Tody slightly blackish, few black spots } \\
\text { goldish and abdomen slightly ass-black }\end{array}$ & $\begin{array}{c}\text { Body Yellowish, few deep spots and abdomen } \\
\text { brownish }\end{array}$ \\
\hline 2 & Tail & Short & Comperatively long \\
\hline 3 & Ana's and Genital papillae & Tubular, Sunken & Round shape, Swollen \\
\hline 5 & Mature ovary and testes & $\begin{array}{c}\text { 1. Testes enlarged ribbon like, creamy } \\
\text { white. }\end{array}$ & $\begin{array}{c}\text { 1. Increase in volume, eggs distinctly visible, } \\
\text { yellowish in colour }\end{array}$ \\
\cline { 3 - 4 } & & $\begin{array}{c}\text { 2. Testes creamy white, soft, occupied } \\
\text { 2/3 of the ventral cavity }\end{array}$ & $\begin{array}{c}\text { 2. Ovary with thin wall, eggs completely round, } \\
\text { translucent, yellow in colour }\end{array}$ \\
\hline 6 & Genital Pressure & Whitish liquid milt & Yellowish fluid \\
\hline 7 & Ripe and gravid condition & Whitish milt from Genital papillae & Yellowish egg from genital papillae \\
\hline
\end{tabular}

Table 1: Identification of male and female maturity stages of M. Cuchia. 


\section{International Journal of Oceanography \& Aquaculture}

The highest GSI of the M. cuchia was a good indicator to reach maturity and the GSI values began to fall gently after spawning from June to December. In case of male $M$. cuchia, the weight of the gonad gradually increased from January to May and reached to a maximum value in May. But in case of female M. cuchia, the weight of the gonad

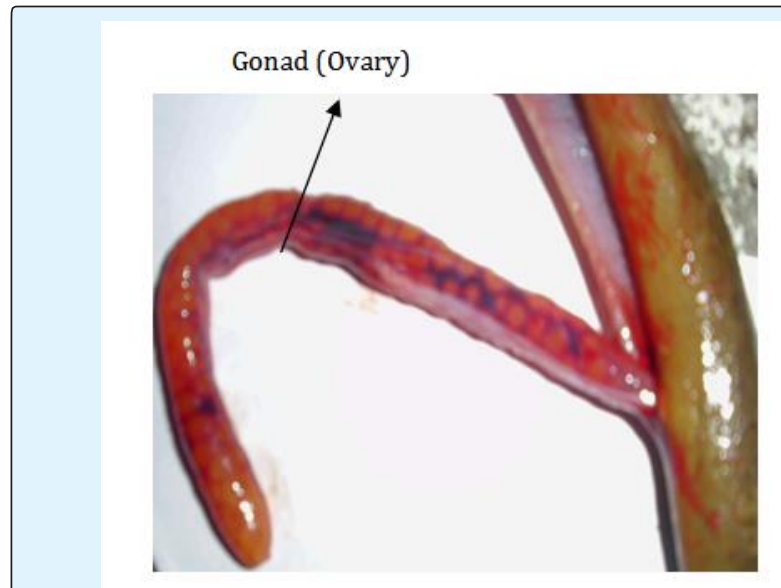

Figure 1a: Female gonad (ovary) of M. cuchia.

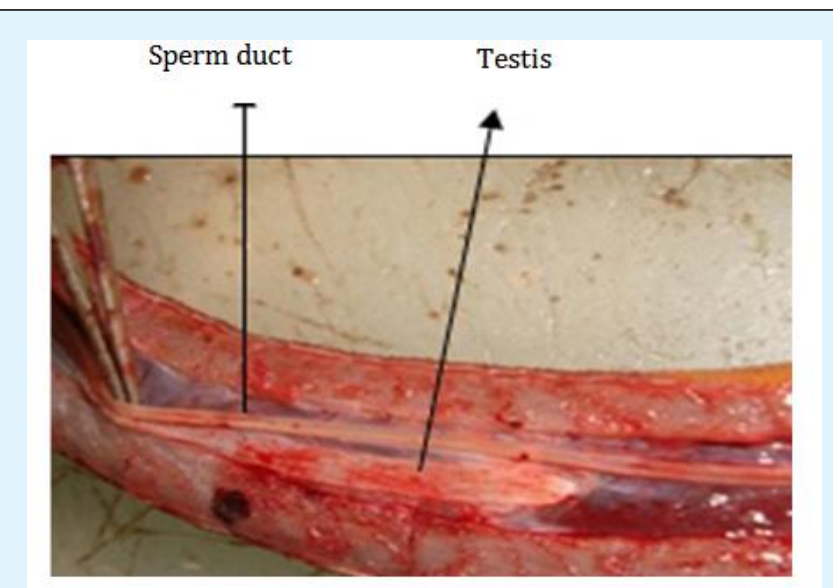

Figure 1b: Male gonad (Testis) of M. cuchia. was increased regularly from January to May. Highest GSI value was recorded in the month of May and the GSI values began to fall gently from June to December. The GSI values for male and female M. cuchia were found to be from $0.09 \pm 0.01$ to $2.80 \pm 0.11$ and $3.70 \pm 0.03$ to $9.81 \pm 0.41$, respectively (Figure 2).

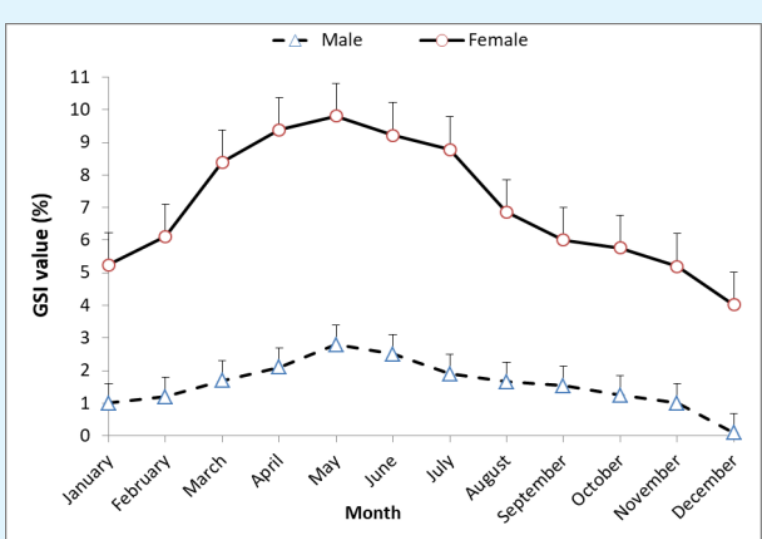

Figure 2: Monthly mean value of gonado-somatic index (GSI) of male and female M. cuchia.

The fecundity was estimated from 62 randomly collected fish samples ranging in total length from $55.68 \pm 5.21$ to $61.10 \pm 5.08 \mathrm{~cm}$, body weight from $320.57 \pm 4.14$ to $440.50 \pm 4.64 \mathrm{~g}$ and ovary weight from $16.80 \pm 1.12$ to $43.20 \pm 1.89 \mathrm{~g}$. The fecundity was found to vary from $506.0 \pm 2.02$ to $1016.0 \pm 3.66$ (Table 2). Condition factor (index) indicated the spawning criteria of M. cuchia. The highest condition index was recorded at the value of 2.119542 for female in May 2017 and lowest was found at the value of 1.857057 in January 2017 (Table 3). The relation between length and fecundity was described by the exponential equation $\ln F=1.3576 \mathrm{e}^{0.1087 \mathrm{x}}, \mathrm{R}^{2}=0.8004$ (Figure 3) and relation between body weight and fecundity was defined by the exponential equation $\ln F=$ $117.2 \mathrm{e}^{0.0049 \mathrm{x}}, \mathrm{R}^{2}=0.6089$ (Figure 4). Finally, relation between gonad weight and fecundity was expressed by the exponential equation and $\ln F=362.35 \mathrm{e}^{0.0229 x}, \mathrm{R}^{2}=$ 0.696 (Figure 5). Length, body weight and gonad weight data were correlated with fecundity.

\begin{tabular}{|c|c|c|c|c|}
\hline Month & MTL \pm SD (cm) & MTW \pm SD (g) & MGW \pm SD (g) & Fecundity \\
\hline January 2017 & $55.68 \pm 5.21$ & $320.57 \pm 4.14$ & $16.80 \pm 1.12$ & $506 \pm 2.02$ \\
\hline February 2017 & $56.42 \pm 6.20$ & $364.62 \pm 4.21$ & $22.20 \pm 1.96$ & $522 \pm 2.11$ \\
\hline March 2017 & $58.0 \pm 5.21$ & $368.11 \pm 3.34$ & $30.90 \pm 1.88$ & $601 \pm 3.33$ \\
\hline April 2017 & $59.88 \pm 4.88$ & $405.82 \pm 4.22$ & $38.08 \pm 2.02$ & $968 \pm 3.45$ \\
\hline May 2017 & $60.05 \pm 4.01$ & $440.05 \pm 4.64$ & $43.20 \pm 1.89$ & $1016 \pm 3.66$ \\
\hline June 2017 & $60.05 \pm 5.23$ & $438.20 \pm 4.11$ & $40.70 \pm 2.44$ & $906 \pm 3.33$ \\
\hline July 2017 & $61.10 \pm 5.08$ & $402.02 \pm 3.86$ & $36.12 \pm 2.01$ & $828 \pm 3.18$ \\
\hline
\end{tabular}

Legend: MTL= Mean total length, SD=Standard deviation, MTW= Mean total Weight, MGW=Mean Gonad Weight.

Table 2: Table shows a relationship among total weight, body weight and gonad weight with fecundity. 


\section{International Journal of Oceanography \& Aquaculture}

\begin{tabular}{|c|c|c|c|c|c|c|}
\hline Month & TF & MTL $\pm S D(\mathrm{~cm})$ & MTW $\pm S D(g)$ & MGW $\pm S D(g)$ & GSI & $\mathbf{K}$ \\
\hline Jan 2017 & 21 & $55.68 \pm 5.21$ & $320.57 \pm 4.14$ & $16.8 \pm 1.12$ & $5.24 \pm 0.18$ & 1.857057 \\
\hline Feb 2017 & 22 & $56.42 \pm 6.20$ & $364.62 \pm 4.21$ & $22.2 \pm 1.96$ & $6.09 \pm 0.22$ & 1.918851 \\
\hline Mar 2017 & 22 & $58.0 \pm 5.21$ & $368.11 \pm 3.34$ & $30.90 \pm 1.88$ & $8.39 \pm 0.28$ & 1.979364 \\
\hline Apr 2017 & 22 & $59.88 \pm 4.88$ & $405.82 \pm 4.22$ & $38.08 \pm 2.02$ & $9.38 \pm 0.33$ & 1.975504 \\
\hline May 2017 & 24 & $60.05 \pm 4.01$ & $440.05 \pm 4.64$ & $43.20 \pm 1.89$ & $9.81 \pm 0.41$ & 2.119542 \\
\hline June 2017 & 23 & $60.05 \pm 5.23$ & $438.20 \pm 4.11$ & $40.70 \pm 2.44$ & $9.22 \pm 0.32$ & 1.969115 \\
\hline July 2017 & 22 & $61.10 \pm 5.08$ & $402.02 \pm 3.86$ & $36.12 \pm 2.01$ & $8.98 \pm 0.32$ & 1.833563 \\
\hline
\end{tabular}

Legend: $\mathrm{TF}=$ Total females, MTL= Mean total length, $\mathrm{SD}=$ Standard deviation, MTW= Mean total Weight, MGW=Mean Gonad Weight, GSI= Gonad somatic Index, K= Condition factor.

Table 3: The relationship between mean Gonadosomatic Index (GSI) and Condition Factor (K) for female M. cuchia with range in paraenthesis.

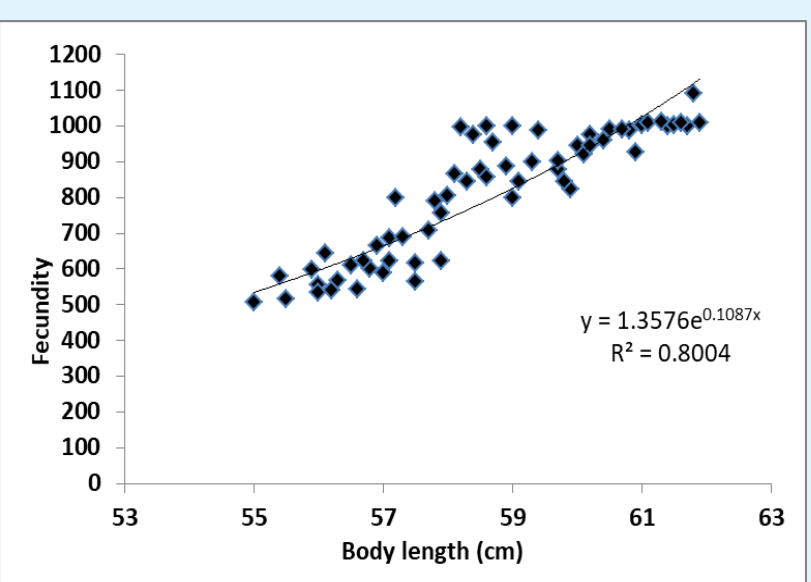

Figure 3: Relationship between fecundity (F) and body length of M. cuchia.

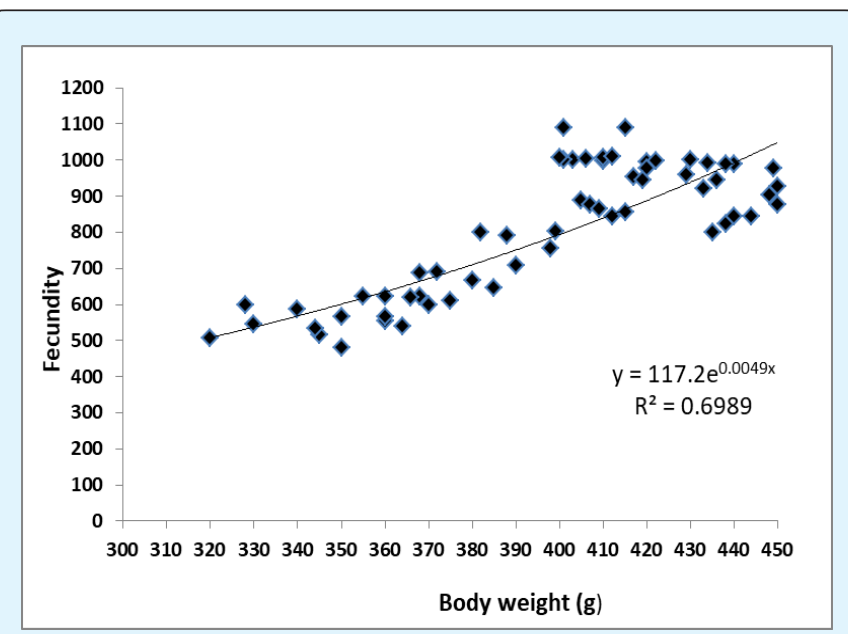

Figure 4: Relationship between fecundity (F) and body weight of $M$. cuchia.

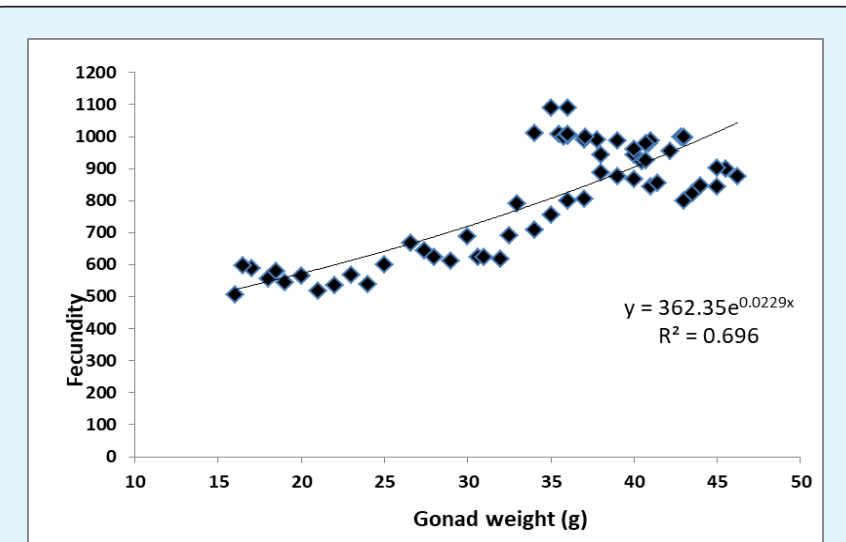

Figure 5: Relationship between fecundity (F) and gonad weight of M. cuchia.

Fertilized eggs of mud eel was collected from in front of the hole and stocked with 10 liter water volume of nine plastic bowls and larvae were cultured for 25 days. After 25 days, the fry was transferred into cement cistern and continued for another 25 days. Pertinent data regarding the fertilization and hatching rate of $M$. cuchia is presented in Table 4. In this method, number of egg collecting holes was recorded at a number of $48.50 \pm 2.83$, $51.00 \pm 1.42$ and $58 \pm 1.54$, and the percentage of responsive number of female fish was at $91.50 \pm 2.12$, $78.50 \pm 2.12$ and $71.00 \pm 2.83 \%$ in treatments $\mathrm{T}_{1}, \mathrm{~T}_{2}$ and $\mathrm{T}_{3}$ which is differed significantly $(\mathrm{p}<0.05)$. The number of collecting eggs from the hole recorded at a number of $9218.50 \pm 65.75,11010.50 \pm 71.42$ and $13642.00 \pm 94.75$ in treatment $\mathrm{T}_{1}, \mathrm{~T}_{2}$ and $\mathrm{T}_{3}$, respectively which is also differed significantly $(\mathrm{p}<0.05)$. The percentage of fertilization was recorded at $94.50 \pm 0.70,89.00 \pm 0.71$ and $85.50 \pm 1.41 \%$ and finally, the hatching rate was at $89.00 \pm 1.41$, $84.00 \pm 1.41$ and $80.50 \pm 0.71 \%$, respectively (Table 4 \& Figure 6). Hatching period was found to be at 60 to $72 \mathrm{hrs}$ 


\section{International Journal of Oceanography \& Aquaculture}

in every treatment. A significant variation was observed in ovulation, fertilization and hatching rate of M. cuchia in three treatments. Control natural breeding of mud eel showed a significant result in ovulation, fertility and hatchability of the treatment $\mathrm{T}_{1}$.
In the study period, it is found that cuchia fish was nocturnal character. So, this fish liked to feed at night. Same initial mean length and weight of $1.81 \pm 0.2 \mathrm{~cm}$ and $0.011 \pm 0.1 \mathrm{~g}$ was stocked in the plastic bowels.

\begin{tabular}{|c|c|c|c|c|c|c|c|}
\hline Treatment & Replication & $\begin{array}{l}\text { Number of egg } \\
\text { collected hole }\end{array}$ & $\begin{array}{c}\text { Collected } \\
\text { fertilized eggs }\end{array}$ & $\begin{array}{c}\text { Responsive } \\
\text { percentage (\%) } \\
\text { of ovulated female }\end{array}$ & $\begin{array}{c}\text { Fertilization } \\
\text { rate (\%) }\end{array}$ & $\begin{array}{c}\text { Hatching } \\
\text { period } \\
\text { (hrs) }\end{array}$ & $\begin{array}{c}\text { Hatching rate } \\
(\%)\end{array}$ \\
\hline \multirow{3}{*}{$\mathrm{T}_{1}$} & $\mathrm{R}_{1}$ & 46 & 9152 & 90 & 94 & \multirow{3}{*}{$60-72$} & 90 \\
\hline & $\mathrm{R}_{2}$ & 49 & 9245 & 93 & 95 & & 88 \\
\hline & Mean & $48.50 \pm 2.83^{c}$ & $9218.50 \pm 65.75^{c}$ & $91.5 \pm 2.12^{\mathrm{a}}$ & $94.50 \pm 0.70^{a}$ & & $89.00 \pm 1.41^{a}$ \\
\hline \multirow{3}{*}{$\mathrm{T}_{2}$} & $\mathrm{R}_{1}$ & 50 & 11161 & 80 & 90 & \multirow{3}{*}{$60-72$} & 85 \\
\hline & $\mathrm{R}_{2}$ & 52 & 10960 & 77 & 88 & & 83 \\
\hline & Mean & $51.00 \pm 1.42^{\mathrm{b}}$ & $11010.50 \pm 71.42$ & $78.5 \pm 212^{b}$ & $89.00 \pm 0.71^{b}$ & & $84.00 \pm 1.41^{b}$ \\
\hline \multirow{3}{*}{$\mathrm{T}_{3}$} & $\mathrm{R}_{1}$ & 55 & 13375 & 73 & 86 & \multirow{3}{*}{$60-72$} & 81 \\
\hline & $\mathrm{R}_{2}$ & 59 & \begin{tabular}{|l|}
13709 \\
\end{tabular} & 69 & 85 & & 80 \\
\hline & Mean & $58.00 \pm 1.54^{a}$ & $13642.00 \pm 94.75^{3}$ & $71.00 \pm 2.83^{c}$ & $85.50 \pm 1.41^{b}$ & & $80.50 \pm 0.71^{c}$ \\
\hline
\end{tabular}

Figures with same letter in the same column are significantly $(\mathrm{p}<0.05)$ different, Values are expressed mean \pm S.D

Table 4: Table showed number of eggs holes, fertilization and hatching rate (\%) of control natural breeding in treatment T1 (Female N=50), T2 (Female $\mathrm{N}=70$ ) and T3 (Female $\mathrm{N}=100$ ).

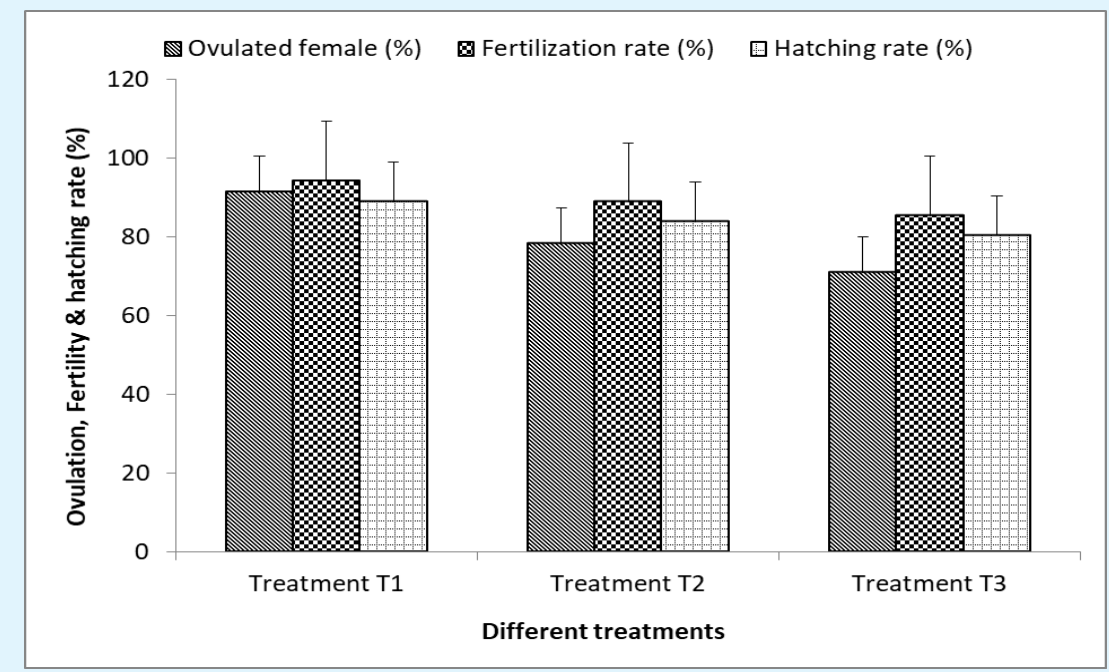

Figure 6: Female ovulation, fertilization and hatching rate (\%) control natural breeding.

After 50 days, the final mean length and weight of fry was recorded at $9.98 \mathrm{~cm}$ and $12.55 \mathrm{gm}$ in treatment $\mathrm{T}_{1}$, $9.73 \mathrm{~cm}$ and $12.30 \mathrm{~g}$ in treatment $\mathrm{T}_{2}$ and $9.54 \mathrm{~cm}$ and $12.08 \mathrm{~g}$ in treatment $\mathrm{T}_{3}$, respectively. Survival and feed conversion ratio (FCR) of $M$. cuchia after 50 days of rearing was recorded at $92.08 \pm 1.65 \%$ and $1.68 \pm 0.02$ in the three treatments. A cycle of control natural breeding technology of M. cuchia is shown in the Figure 7. 


\section{International Journal of Oceanography \& Aquaculture}

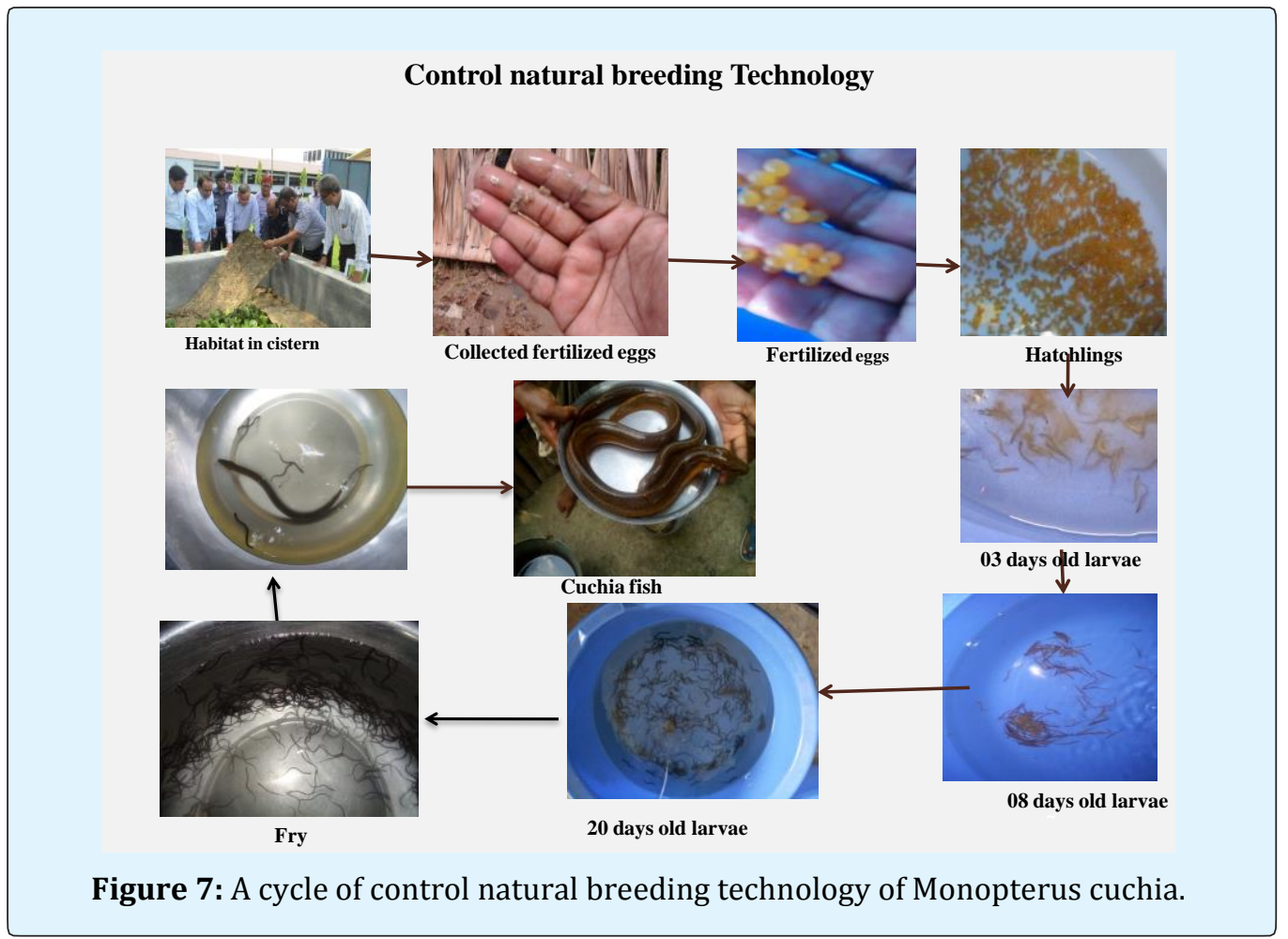

During the experimental period, the water quality parameters of cistern such as temperature $\left({ }^{\circ} \mathrm{C}\right)$, dissolved oxygen (mg.l-1 $), \mathrm{pH}$ and total alkalinity (mg.l-1) were measured regularly (Table 5). A lower temperature (18.0
oC) was found in treatment $\mathrm{T}_{3}$ due to geographical location. No significant variation of other water quality parameters was observed during the study period in all the treatments.

\begin{tabular}{|c|c|c|c|}
\hline \multirow{2}{*}{ Parameters } & \multicolumn{3}{|c|}{ Treatments } \\
\cline { 2 - 4 } & $\mathbf{T}_{\mathbf{1}}$ & $\mathbf{T}_{\mathbf{2}}$ & $\mathbf{T}_{\mathbf{3}}$ \\
\hline Water Temp. $\left({ }^{\circ} \mathrm{C}\right)$ & $30.29 \pm 1.50$ & $28.92 \pm 1.62$ & $27.41 \pm 1.15$ \\
\hline $\mathrm{pH}$ & $7.97 \pm 0.42$ & $7.91 \pm 0.39$ & $7.98 \pm 0.31$ \\
\hline Dissolved oxygen $(\mathrm{mg} / \mathrm{l})$ & $6.41 \pm 1.05$ & $6.98 \pm 1.02$ & $6.02 \pm 1.10$ \\
\hline Alkalinity $(\mathrm{mg} / \mathrm{l})$ & $190.12 \pm 2.46$ & $192.00 \pm 2.22$ & $188.88 \pm 1.06$ \\
\hline
\end{tabular}

Table 5: Water quality parameters of $M$. Cuchia natural breeding in Cistern.

\section{Discussion}

Some workers of Bangladesh tried to use different hormone for successful induced breeding. No record of induced breeding was established in aquaculture book of Bangladesh still now. Miah MF, et al. [15] reported that the eggs and oviduct tissues of M. cuchia was damaged in almost all the induced female fish. So, control natural breeding was followed depending on lower fecundity, complication of handling and harvesting system of the fish.

M. cuchia was stocked at a density of male and female 50:50, 70:70 and 100:100 in treatment $\mathrm{T}_{1}, \mathrm{~T}_{2}$ and $\mathrm{T}_{3}$ to identify a suitable stocking range of brood for breeding. In this method, number of egg collecting holes recorded at a number of $48.50 \pm 2.83,51.00 \pm 1.42$ and $58 \pm 1.54$. The number of holes was lowest due to lowest number of stocking density in treatment $\mathrm{T}_{1}$. The number of collecting eggs from the hole recorded at a number of $9218.50 \pm 65.75,11010.50 \pm 71.42$ and $13642.00 \pm 94.75$ in treatment $\mathrm{T}_{1}, \mathrm{~T}_{2}$ and $\mathrm{T}_{3}$. The collecting number of fertilized eggs was highest in treatment $T_{3}$ then $T_{2}$ and $T_{1}$ due to higher number of brood was stocked in treatment $\mathrm{T}_{3}$ and $\mathrm{T}_{2}$. The percentage of responsive number of female fish was at $91.50 \pm 2.12,78.50 \pm 2.12$ and $71.00 \pm 2.83 \%$ and fertility rate was recorded at $94.50 \pm 0.70,89.00 \pm 0.71$ and $85.50 \pm 1.41 \%$ and finally, the hatching rate was at $89.00 \pm 1.41,84.00 \pm 1.41$ and $80.50 \pm 0.71 \%$. In this study, 


\section{International Journal of Oceanography \& Aquaculture}

stocking density of male and female 50:50 in treatment $\mathrm{T}_{1}$ showed highest responsive percentage (\%) of ovulated female, fertilization rate and hatching rate than treatment $\mathrm{T}_{2}$ and $\mathrm{T}_{3}$. This may be due to suitable temperature, geographical location, space, food competition, selection of suitable recipient fish at the proper stage of ovarian development and creation of congenial spawning conditions [16]. The success of entire operation of control natural breeding was depended on proper selection of brood fishes [17]. In this study, yolk absorption period of cuchia larvae's was completed among 10-12 days and some young larvae actively engaged feeding [18].

Reproductive cycle of M. cuchia was studied to observe the pattern and timing of growth phase and maturation stages of the gonad of male and female individual. GSI was an indicator of the reproductive activity of a stock [19]. The GSI increased highest level during the peak period of maturity and declined abruptly after spawning [20]. The results of the present experiment indicated that the GSI of M. cuchia was highest during May and the percentage of yolk laden ripe eggs in ovary was found in May $[10,21]$. The variation of mean GSI occurred in mature fishes and indicated the peak period of spawning [22]. Females were considered gravid and possessed developing ova [23].

Condition factor expresses the general well-being of a fish. In this study, condition factor was recorded as a good index and a good condition factor was found in May 2017 [24]. According to Bagenal TB [24] and Tesch FW a condition factor of less than one means the fish is starving and generally not in good condition. An index of 1.0-1.2 means the fish is doing well and 1.4 shows the fish is near spawning. A good condition index about 2.119542 was recorded for female in May 2016 [25]. Relationship between fecundity and body weight, fecundity and total length, and fecundity and gonad weight was found very significant [26]. Higher fecundity of fish was recorded with the increase of body weight, total length and gonad weight. A significant co-efficient of correlation between fecundity and total length, fecundity and body weight, and fecundity and gonad weight was found in the May [27].

In case of fecundity study, Von Vayer method was established to be suitable for relatively large eggs of $M$. cuchia [12]. Von Vayer method was found to be more efficient than the other methods and gave fairly accurate results $[21,22,28]$. This species belonging to the same size group had varying in number of eggs in their ovaries. Lagler KF, et al. [29] reported that the number of eggs produced by a female was dependent on various factor like size, age and condition of the species.

\section{Conclusion}

Induced breeding of $M$. Cuchia has not been yet successful. The habitat of cuchia is not like other fishes of Bangladesh. M. cuchia lives in a hole. So, it is not easy to harvest by net. The fecundity of cuchia is very low. It is evident from the findings of the present study that stocking density of male and female 50:50 (1:1) in treatment $\mathrm{T}_{1}$ was very sustainable technology for control natural breeding. Control natural breeding is the most successful and sustainable aquaculture method for seed production of M. Cuchia. This technology would be established in the aquaculture field of Bangladesh and protected this endangered species from extinction as well as for its rehabilitation.

\section{Acknowledgements}

The authors gratefully acknowledge the financial support of Culture of cuchia and crab in the selected area of Bangladesh and research project, Bangladesh and are thankful to the department of Fisheries for kind support and cooperation.

\section{References}

1. Talwar PK, Jhingran AG (1991) Inland fishes of India and adjacent countries. Vol. 2. Oxford and IBH Publishing, New Delhi, Bombay, Calcutta.

2. Rahman AKA (1989) Fresh water Fishes in Bangladesh, pp: 263-264.

3. Disaster E (1990) Floodplain protection in Central Europe. World Wildlife Found (WWF) Institute of Floodplains Ecology Visiting Card 31/90, Germany.

4. Chakraborty BK, Azad SA, Bormon B, Ahmed M, Faruque AMO (2010) To investigate the technical and co-management aspects of mud eel (Monopterus cuchia) culture by ethnic (Adivasi) communities in the Northern Bangladesh. J Crop and Weed 6(2): 1925.

5. Jamir NS, Lal P (2005) Ethnozoological practices among Naga tribes. Indian J Tradit Knowle 4(1): 100104.

6. Kakati LN, Bendong A, Doulo V (2006) Indigenous knowledge of zootherapeutic use of vertebrate origin by the Ao Tribe of Nagaland. J Hum Ecol 19(3): 163167. 


\section{International Journal of Oceanography \& Aquaculture}

7. Saikia K, Ahmed R (2012) Wetland fish biodiversity of Majuli river island (India) and their medicinal values. The Clarion: Multidisciplinary Int J 1(2): 365-372.

8. Chakravorty S, Kalita JC (2012) An investigation of anti-diabetic medicinal plants used by villagers in Nalbari district, Assam, India. Int J Pharm Sci Res 3(6): 1693-1697.

9. Mishra N, Padey PK, Munshi JSD (1977) Some aspect of Hematology of an air breathing Indian mud eel, Amphipnous cuchia. Jpn J Ichthyol 24(3): 176-181.

10. Chakraborty BK (2018) Present Status of Mud Eel, Monopterus Cuchia (HamiltonBuchanan, 1822) in Bangladesh. Progress in Aqua Farming and Marine Biology 1(1): 1-12.

11. Jhingran AG, Verma DN (1972) Sexual maturity and spawning of Gadusia chapra (Ham.) in Ganga river system. Proc Nat Sci Acad India 42(2): 207-224.

12. Lagler KF (1956) Freshwater Fishery Biology $2^{\text {nd }}$ (Edn.), WMC Brown Company, Bubuque, Lowa, UK, pp: 541.

13. Brown ME (1957) Experimental studies on growth. In: The physiology of fishes. Academic Press, New York 1: 361-40.

14. APHA (1976) Standard methods for the examination of water and waste water. 14th (Edn.), American Public Health Association, Washington DC, USA, pp: 1193.

15. Miah MF, Ali H, Zannath E, Shuvra TM, Naser MN, et al. (2015) Breeding biology and induced breeding status of freshwater mud eel, Monopterus cuchia. International J Bioengineering and Life Sciences 9(6): 680-684.

16. Nash CE, Shehadesh ZH (1980) Review of breeding and Propagation Techniques for Grey Mullet, Mugil Cephalus L. ICLARM Studies 3, Manila, Phillipines, pp: 87.

17. Lokman PM, Young G (2000) Induced spawning and early ontogeny of New Zealand freshwater eels (Anguilla dieffenbachia and A. australis). New Zealand J Marine \& Freshwater Res 34(1): 135-145.

18. Banerji SR, Singh ML, Thakur NK (1981) Observation on Natural breeding and larval development of the common mud eel Amphipnous Cuchia (Ham.), Hydrologia 79(2): 147-155.
19. Devlaming V, Grossman GD, Chapman F (1982) On the use of the gonado-somatic index. Com Biochemis and Physiol 73(1): 31-39.

20. Le Cren ED (1951) The length-weight relationship and seasonal cycle in gonad weight and condition in perch, Perca fluviatilis. J Anim Ecol 20(2): 201-219.

21. Chakraborty BK (2010) Fecundity and Induction of spawning in spiny Guchi, Marognathus pancalus (Bloch \& Schneider, 1822) in Bangladesh. Bangladesh J Zool 38(1): 77-91.

22. Chakraborty BK, Azad SA, Barmon B, Faruque AMO (2013) Fecundity and Gonado Somatic Index of Gangetic mud eel, Monopterus cuchia (Hamilton, 1922). Bangladesh Journal of Zoology 41(2): 165-172.

23. Haynes JL, Cashner RC (1995) Life history and population dynamics of the Western mosquitofish: a comparison of natural and introduced populations. Journal of Fish Biology 46(6): 1026-1041.

24. Bagenal TB (1978) Method of Assessment of fish production in fresh waters. $3^{\text {rd }}$ (Edn.), Oxford Backwell Scientific Publication, Philadelphia, pp: 101136.

25. Alhassan EH, Abobi SM, Mensah S, Boti F (2014) The spawning pattern, Length-weight relationship and condition factor of elephant fish, Mormyrus rume from the Bontanga Reservoir, Ghana. Int J Fisheries Aquatic studies 2(2): 109-114.

26. Galerida RP, Nader H, Ivan P (2012) Spawning, Sex Ratio and Relationship between Fecundity, Length, Weight and Age of Chub (Squalius cephalus L., 1758) in the Middle Stream of Iskar River (Bulgaria). Acta Zool Bulg 64(2): 191-197.

27. Nirmal S, Gupta PK (2014) Reproductive biology of eastern mosquito fish Gambusia holbrooki (Girard) (Poeciliiadae) in a sub-tropical Lake, Lake Nainital (India). Int J Cur r Microbiol App Sci 3(4): 19-31.

28. Philips GL (1969) Accuracy of fecundity estimation for the minnow, Chrosomus erythrogasrer (Cyprinidae). Trans Amer Fish Soc 98: 524-526.

29. Lagler KF, Bardach JE, Miller AR (1967) Ichthylogy. John Wiley \& Sons, New York, USA, pp: 545. 